\title{
Productive performance of broiler chickens fed tomato waste
}

\section{Rosa Cavalcante Lira ${ }^{1}$, Carlos Bôa-Viagem Rabello², Maria do Carmo Mohaupt Marques Ludke², Paulo Vanderlei Ferreira ${ }^{1}$, Geraldo Roberto Quintão Lana ${ }^{1}$, Sandra Roselí Valerio Lana ${ }^{1}$}

${ }^{1}$ Centro de Ciências Agrárias da Universidade Federal de Alagoas - UFAL, Macéio, Alagoas, Brasil.

${ }^{2}$ Departamento de Zootecnia da Universidade Federal Rural de Pernambuco - UFRPE. Av. Dom Manoel de Medeiros, s/n, CEP: 52170-900, Recife, Pernambuco, Brasil.

ABSTRACT - Aiming to evaluate the effect of tomato waste inclusion on productive performance and characteristics of carcass and main broiler chicken cuts, an experiment was carried out using 300 male Cobb chicks, distributed in a complete randomized design, with five rations and five replicates. Diets consisted of control ration based on corn and soybean meal and four rations with 5, 10, 15 and 20\% of tomato waste. Feed intake, weight gain and feed conversion and, at the end of experiment, slaughter weight, gutted carcass without feet and head, breast, drumstick, thigh, wing, back, edible guts and belly fat were evaluated every week, as well as it was the yield. Tomato waste increased feed intake in the periods from 1 to 7 , 8 to 14 and 29 to 36 days of age and worsened gain weight and feed conversion of broiler chickens up to 29 days of age. Regarding carcass weight (g) and weight of the noble parts, breast, drumstick and thighs decreased linearly in function of the use of tomato waste in poultry on pre- initial and initial phase, that is, up to 28 days old, but yield (\%) was not affected except for yield of heart and liver. Use of tomato waste in ration of broiler chickens during the period from 1 to 28 days may decrease weight gain and worsen food conversion. Tomato waste may be used as ration ingredient in ration of broiler chicken in the breeding period from 29 to 42 days of age up to the level of $20 \%$ without harming weight gain and feed conversion of poultry.

Key Words: agro industrial by-product, carcass, weight gain

\section{Desempenho produtivo de frangos de corte alimentados com resíduo do tomate}

RESUMO - Com o objetivo de avaliar o efeito da inclusão do resíduo do tomate sobre o desempenho produtivo e as características da carcaça e dos principais cortes de frangos de corte, foi realizado um experimento com 300 pintos machos Cobb, distribuídos em delineamento inteiramente casualizado, com cinco rações e cinco repetições. As dietas consistiram de uma ração-referência à base de milho e farelo de soja e quatro rações com 5, 10, 15 e 20\% de resíduo do tomate. Foram avaliados, semanalmente, o consumo de ração, o ganho de peso e a conversão alimentar e, no final do experimento, os pesos de abate, carcaça eviscerada, carcaça sem pés e cabeça, de peito, coxa, sobrecoxa, asa, dorso, vísceras comestíveis e gordura abdominal, bem como seus rendimentos. O resíduo de tomate aumentou o consumo de ração nos períodos de 1 a 7,8 a 14 e 29 a 36 dias de idade, mas piorou o ganho de peso e a conversão alimentar dos frangos de corte até 29 dias de idade. Os pesos de carcaças (g) e das partes nobres, peito, coxa e sobrecoxas diminuíram linearmente como consequência do resíduo no peso das aves nas fases pré-inicial e inicial, ou seja, até 28 dias de idade. Os rendimentos (\%) dessescortes não foram afetados pelo uso de resíduo de tomate, exceto os rendimentos de coração e fígado. O uso de resíduo de tomate em rações para frangos de corte durante o período de 1 a 28 dias pode diminuir o ganho de peso e piorar a conversão alimentar. O resíduo de tomate pode ser utilizado em níveis de até $20 \%$ em rações para frangos de corte no período de 29 a 42 dias de idade, pois nesse nível não prejudica o ganho de peso nem a conversão alimentar das aves.

Palavras-chave: carcaça, ganho de peso, subprodutos agroindustriais

\section{Introduction}

The market of ration for monogastrics absorbs more than $60 \%$ of the annual production of corn and soybean meal, fundamental ingredients in rations for these animals, responsible for $80 \%$ of its final price, because of human competition and production below of the expected, which generates a demand greater than the offer (Rodrigues et. al., 2004). Therefore, it has increased the interest for alternative food that may be used in diets for monogastrics, and which do not harm performance, and might replace corn and soybean meal in ration, aiming to

Received July 8, 2008 and accepted August 19, 2009.

Corresponding author: cbviagem@dz.ufrpe.br 
reducing cost and assuring adequate nutritional value of regimes (Soares et al., 2007).

Primary or industrial processing of food destined to animal and human feeding has been responsible for high production of residues, which, in spite of pollutant power, is nutritionally potential to be used to formulate diets for monogastrics (Ezequiel et al., 2006). In this context, agro industries are highlighted, such as tomato processing, which generates approximately 832,000 t in Brazil (IBGE, 2005 ), resulting in an estimated production of $30 \%$ of byproduct with $20 \%$ of crude protein (Kronka et al., 1971).

This residue has been used in animal feeding, mainly for ruminants, in regions close to processing industries, without considering nutrient content and the best level of inclusion (Ribeiro et al., 2004).

The use of tomato waste in feeding of monogastrics is practicable, mainly for broiler chickens, because there are few literatures of assays regarding performance and evaluation of carcass yield. In this aspect, working with broiler chickens from 8 to 21 days of age, Persia et al. (2003) used residues from tomato in the levels of $0 \% ; 5 \% ; 10 \%$; $15 \%$ and $20 \%$ in relation to corn and soy meal and observed that the performance of the fowls had no negative effect in gain of weight and in feed efficiency up to level of $15 \%$.

This work was carried out with the objective of evaluating the effect of using tomato waste on the productive performance and carcass characteristics of broiler chickens.

\section{Material and Methods}

The experiment was carried out in the Departamento de Zootecnia, Universidade Federal de Alagoas, from December $14^{\text {th }}, 2007$ to January $24^{\text {th }}, 2008$. It was used 3001 -d male chicks, Cobb strain, vaccinated at hatchery against diseases such as Marek, Gumboro and Newcastle and selected according to initial mean weight of approximately $41 \mathrm{~g}$.

The fowls were placed in a masonry east-west oriented shed, with 52 boxes $(1.00 \times 1.25 \mathrm{~m})$, concrete floor, covered with 3-meter high asbesto cement shingles, with chicken wire, protected with polyethylene curtains on the sides, which were managed according to temperature conditions and gas concentration within the shed.

Tubular feeders and pressurized drinking fountains for young chicks were used until the second week, when they were replaced by tubular feeders and bell drinker for adults in the same proportion per box. Artificial heating for chicks in each experimental parcel was carried out up to the 15th day of placing, by using incandescent light bulbs of 100 watts, installed over $20 \mathrm{~cm}$ from the ground and regulated according to growth and environment temperature.

Artificial illumination was performed with incandescent light bulbs of 100 watts in a continuous program of 24 hours of light. Monitoring of climatic variables was carried out daily, at 8 a.m. and at 4 p.m., by means of meteorological station containing a black globe thermometer, a wet bulb thermometer, dry bulb thermometer and a maximum and minimum thermometer, whose data was used for maximum temperature calculus, minimum temperature, relative humidity, temperature of black globe and wet bulb globe temperature in experimental phases. Wet bulb globe temperature index was obtained according to Buffington et al. (1981).

The chicks were distributed in a randomized complete design in order to evaluate five rations that composed experimental treatments, each one with five replicates with 12 chicks. The experimental rations, all of which were isoenergetic and iso-nutrient, were formulated based on corn and soybean meal and contained 0, 5, 10, 15 and 20\% of tomato waste (Table 1).

In order to formulate rations, tables of food composition and nutritional requeriments by Rostagno et al. (2005) were used, considering that values of tomato waste, chemical composition and energetic value $(2,645 \mathrm{kcal} / \mathrm{kg})$ were determined in other works by the same author and used here (Lira, 2008) and values for amino acid determined by Silva et. al. (2008) considering that it was turned into digestible amino acids based on coefficient of digestibility determined by Pérsia et al. (2003).

Feeding program was constituted by four phases (1 to 7 days, 8 to 21 days, 22 to 35 days and from 36 to 42 days) and ration was provided ad libitum during the whole experimental period. Feed intake and weight gain were quantified weekly in each parcel, next, calculations of food conversion were carried out.

At 42 days of age, two birds were selected by weight mean and fasted for 6 hours. Next, the birds were weighed again, identified and slaughtered to determine the weight of the eviscerated carcass with feet and head, breast, drumstick, thigh, wing, dorsum, gizzard (with fat), liver, heart and abdominal fat (cloacae and gizzard region). The yield of the eviscerated carcass with feet and head was determined in relation to weight at slaughter, while the parts were determined in relation to the eviscerated carcass weight with feet and head.

Regression equation to evaluate level of tomato waste were adjusted by using software Sisvar - Sistema de análises estatística (System of statistical analysis) - DEX/UFLA (Ferreira, 2003), observing all variables, established by 


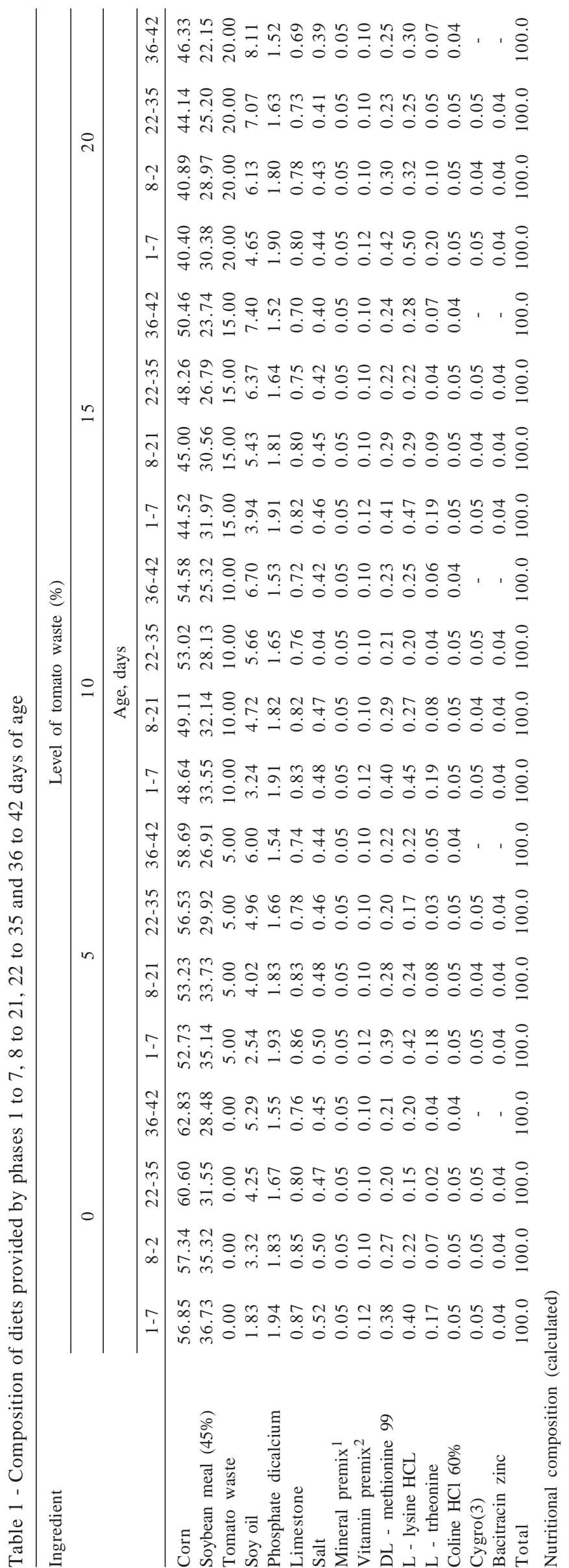

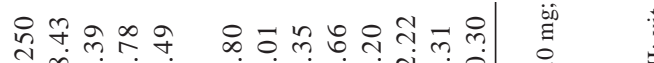
mं

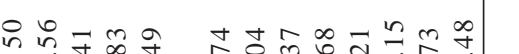
ली

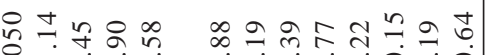

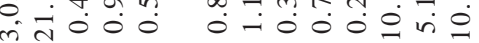

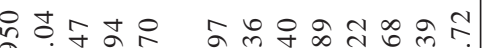
î

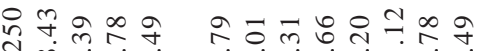
min

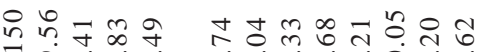
लं

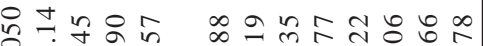

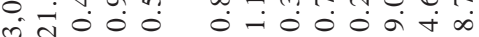

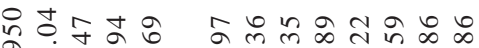
4.

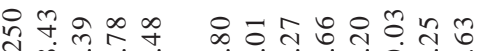
mं

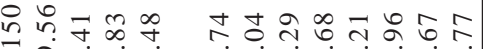
ले

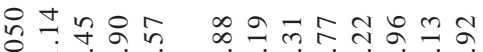

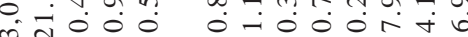

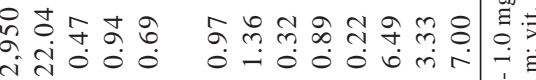

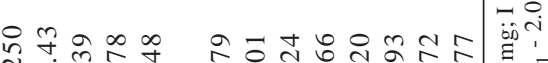

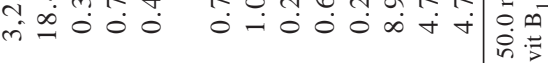

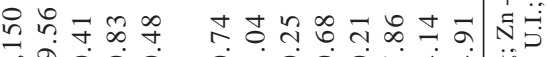
mं

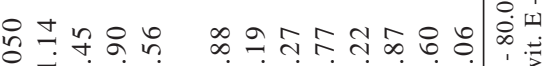

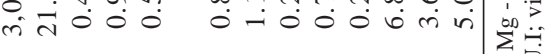
员英金吉怘 ते

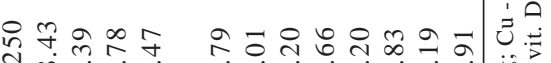

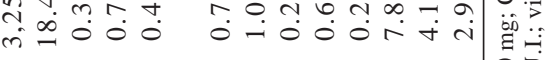

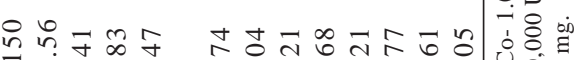
ले

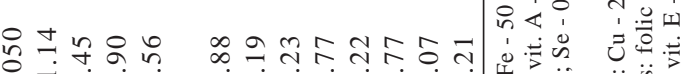
लं

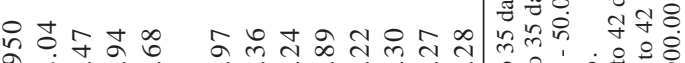

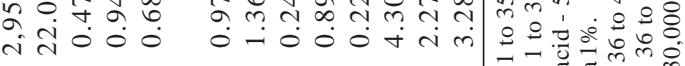

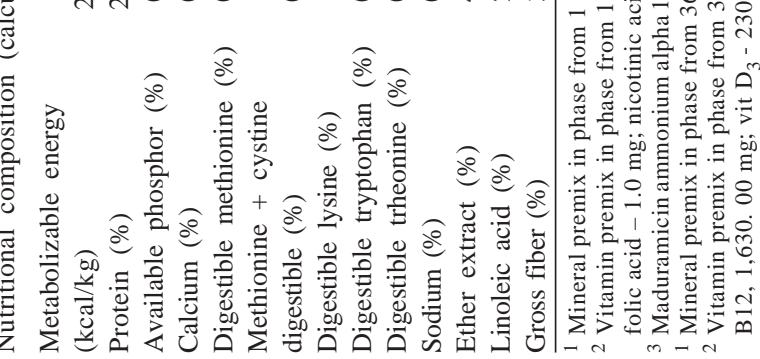


linear or quadratic regression model, according to the best adjustment.

\section{Results and Discussion}

Temperature, relative air humidity and wet bulb globe temperature index values were above the optimum (Table 2 ), characterizing thermal discomfort, mainly in phases posterior to the third week, when temperature value should be between 20 and $26^{\circ} \mathrm{C}$, and relative humidity of air between 60 and 70\%, according to Abreu \& Abreu (2000), and maximum wet bulb globe temperature index of 76 (Teixeira, 1983), for better yield results.

Levels of tomato waste inclusion influenced feed intake of broiler chickens from 1 to 7 days of age and from 36 to 42 days of age, according to equations of linear regression presented (Table 3 ). At about $1 \%$ of tomato waste inclusion, there was a feed intake decrease of $0.95 \mathrm{~g} /$ bird/week in the first week and an increase of $6.774 \mathrm{~g} / \mathrm{bird} /$ week in the 36-42 day period. In the 8-14 day period, however, there was a quadratic response indicating that $5.64 \%$ level of tomato residue provided a better result of consumption in this period (Table 3).

According to Parson et al. (1985), fiber content of experimental ration may affect intestinal transit and decrease the passage of food through gastrointestinal tract, because soluble portion of bran in contact with water forms a gel that reduces passage time of food by promoting sensation of satiety and reduction of ration consumption. Therefore, in the first week, a negative effect of tomato waste level occurred due to great sensitivity of young fowls to ingestion of diets with high content of bran (Cavalcante et al., 2007). Moreover, granulometry of ration may have influenced regime ingestion through particle selection by chicks in this period.

In the week before, a contrary effect was verified, with an increased consumption of bran portion. This result is in accordance with the results obtained by Loureiro et al. (2007) in an experiment with the same ingredients for commercial laying hens. Authors observed the same behavior on the effects of bean over passage rate, which reduces absorption of nutrients and increases consumption to compensate and meet nutritional demands of high yield fowls.

In other experimental periods (15 to 21 days, 22 to 28 days, 29 to 35 days and from 1 to 42 days) consumption was not affected by tomato waste inclusion, and the observed means were: 801.20; 1,042.09; 1,212.55; and 5,027.61 g, respectively. The same behavior was verified by Al-Betawi (2005) in an experiment with chicken broiler with inclusion of up to $15 \%$ of tomato waste in ration. The results are also in accordance to what was described by Cavalcante et al. (2007), who used in ration of broiler chicken in a 1-42 day period up to $17.5 \%$ of coconut meal, which has bran composition similar to tomato waste.

Level of tomato waste in ration had quadratic effect in weight gain in 1-7 day phase. Maximum weight gain was found by including $1.71 \%$ of tomato waste in rations, however, in 8-14 day, 15-21 day, 22-28 day and 1-42 day periods, the effect was linear, so that, for each $1 \%$ of inclusion there was a reduction of $2.4 ; 3.5 ; 3.4$ and 8.3 g/bird/week, respectively (Table 3). In phases from 29 to 35 days and from 36 to 42 days, there was no difference between diets, but means of 596.56 and 590.29 g were observed, evidencing a lower effect of fiber in final phases of the experiment. This result may be related to ingestion and digestion capacity increase as the birds get older, since these adult fowls seem to be able to fit to high bran content ratios once digestive treat is sufficiently developed to reduce or neutralize negative effects of fibrous portion after 21 days (Potter et al., 1990; Philip et al., 1995).

Persia et al. (2003) also observed significant reduction in weight gain of broiler chickens in the 8-21 day phase as the tomato waste level increase; however, Cavalcante et al. (2007) verified reduction of weight gain of broiler chickens in initial phase (7 to 21 days) after increasing coconut meal inclusion in rations, a fact also attributed to increase of bran content in ration with higher level of coconut residue inclusion, which may have prevented hydrolytic action of enzymes by making it difficult the contact of these enzymes with starch granules, protein and fat molecules of food and decreased the contact among nutrients with abortive cells

Table 2 - Week mean values for climatic variables in the experimental phases

\begin{tabular}{lcccc}
\hline Phase (days) & $\begin{array}{c}\text { Maximum temperature } \\
\left({ }^{\circ} \mathrm{C}\right)\end{array}$ & $\begin{array}{c}\text { Minimum temperature } \\
\left({ }^{\circ} \mathrm{C}\right)\end{array}$ & $\begin{array}{c}\text { Relative humidity } \\
(\%)\end{array}$ & $\begin{array}{c}\text { Black globe } \\
\text { temperature }\left({ }^{\circ} \mathrm{C}\right)\end{array}$ \\
\hline 1 to 7 & $33.06 \pm 1.80$ & $24.77 \pm 2.91$ & $78.00 \pm 2.30$ & $31.04 \pm 2.29$ \\
temperature & index
\end{tabular}


of intestinal membrane leading to a reduction in digestion and absorption of ration nutrients (Parson et al., 1985), which resulted in a low performance (Corsins, 1999). Additionally, high content of fiber allows exaggerated multiplication of intestinal bacteria which may reach superior portions of jejunum producing acids which degrade enzymes in charge of digestion (Torres, 2003).

Loureiro et al. (2007) also observed decrease in egg yield in laying hens when using levels above $5 \%$ of tomato meal in ration. Linear effect of inclusion levels also occurred in phases from 1 to 7 days; 8 to 14 days, 15 to 21 days; and 1 to 42 days, in which each $1 \%$ of residue inclusion caused an increase of $0.0084 ; 0.0056 ; 0.0084$ and $0.008 \mathrm{~kg}$, respectively, in the index of conversion (Table 3 ). In the 22-28 day period, quadratic effect and the worst point of conversion were the ones in which fowl consumed $2.25 \%$ of tomato waste. These results indicated that bran content possibly interfered in the use of nutrients of rations containing higher amounts of tomato waste. Jafari et al. (2006) also observed decrease of food efficiency in laying hens at 27 to 38 weeks of age with the inclusion of levels up to $15 \%$ of tomato waste in their diets, and Cavalcante et al. (2007) obtained significant increase of food conversion in initial and final phases of broiler chickens with diet level up to $17.5 \%$ of coconut meal, but did not observed effects in total breeding period (1 to 42 days).
In 29-35 day and 36-42 days phases, no effects were observed among inclusion levels, but the means in these phases were 2.04 and $2.23 \mathrm{~kg}$, respectively. Loureiro et. al. (2007) also obtained similar results when using tomato waste levels of $0,5,10,15$ and $20 \%$ in rations of commercial laying hens from 30 to 39 weeks of age, with linear effect in some phases (33 to 39 weeks) and no significant effect between diets in others (30 to 33 weeks) as tomato waste level in regime of commercial laying hens. However, Persia et al. (2003) observed quadratic effect of level of up to $15 \%$ of inclusion in food efficiency of broiler chickens from 8 to 21 days of age.

There was no difference among diets for absolute weight at slaughter and breast weight neither for yield of gutted carcass, gutted carcass without feet and head, breast, drumstick and thigh, which indicates that alterations in ration consumption and weight gain in some phases promoted by inclusion of tomato waste were not enough to affect yield of these cuts, which presented respective means for absolute weight of 2,816.70 $\mathrm{g}$ and $730.92 \mathrm{~g}$ and for relative weight $88.79 ; 82.63 ; 29.22 ; 11.68$ and $13.94 \%$, respectively (Table 4$)$.

Cavalcante et al. (2007) observed no differences among diets when using levels of inclusion up to $17.5 \%$ of coconut meal, which has similar chemical composition to tomato waste, in yield on broiler chickens carcass. However, for

Table 3 - Means of performance characteristics of broiler chickens, in different phases, fed rations containing tomato waste

\begin{tabular}{|c|c|c|c|c|c|c|c|c|}
\hline \multirow[t]{2}{*}{ Item } & \multirow[t]{2}{*}{ Phase (days) } & \multicolumn{5}{|c|}{ Level of tomato waste (\%) } & \multirow[t]{2}{*}{$\mathrm{CV}$} & \multirow[t]{2}{*}{ F (\%) } \\
\hline & & 0 & 5 & 10 & 15 & 20 & & \\
\hline \multirow[t]{6}{*}{ Feed intake (g) } & 1 to 7 & 199.17 & 194.42 & 189.67 & 184.92 & 180.17 & 7.67 & $5.33 * 1$ \\
\hline & 8 to 14 & 462.85 & 468.38 & 465.09 & 452.97 & 432.04 & 3.37 & $5.77 * 2$ \\
\hline & 15 to 21 & 799.50 & 802.82 & 816.95 & 815.48 & 771.24 & 4.72 & $1.18 \mathrm{~ns}$ \\
\hline & 22 to 28 & $1,032.00$ & $1,019.50$ & $1,070.25$ & $1,032.32$ & $1,056.36$ & 4.25 & $1.09 \mathrm{~ns}$ \\
\hline & 29 to 35 & $1,168.58$ & $1,184.83$ & $1,199.33$ & $1,290.08$ & $1,219.92$ & 6.66 & $1.71 \mathrm{~ns}$ \\
\hline & 1 to 42 & $4,915.21$ & $4,971.72$ & $5,052.00$ & $5,165.62$ & $5,033.50$ & 4.20 & $0.99 \mathrm{~ns}$ \\
\hline \multirow[t]{6}{*}{ Weight gain (g) } & 1 to 7 & 173.31 & 172.56 & 166.15 & 154.10 & 136.39 & 3.94 & $13.99 * * 4$ \\
\hline & 8 to 14 & 359.73 & 347.51 & 335.29 & 323.07 & 310.85 & 5.56 & $21.47 * * 5$ \\
\hline & 15 to 21 & 573.61 & 555.98 & 538.34 & 520.71 & 503.08 & 5.25 & $19.48 * * 6$ \\
\hline & 22 to 28 & 608.29 & 591.45 & 574.62 & 557.78 & 540.94 & 4.47 & $21.49 * * 7$ \\
\hline & 29 to 35 & 582.41 & 597.08 & 554.33 & 643.64 & 605.33 & 10.09 & $1.48 \mathrm{~ns}$ \\
\hline & 36 to 42 & 586.54 & 581.76 & 584.35 & 590.92 & 607.86 & 8.12 & $0.23 \mathrm{~ns}$ \\
\hline \multirow{6}{*}{ Feed conversion (kg/kg) } & 8 to 14 & 1.30 & 1.33 & 1.36 & 1.39 & 1.41 & 3.94 & $13.50 * * 10$ \\
\hline & 15 to 21 & 1.41 & 1.45 & 1.49 & 1.53 & 1.58 & 5.86 & $11.42 * * 11$ \\
\hline & 22 to 28 & 1.73 & 1.73 & 1.78 & 1.86 & 1.99 & 3.56 & $6.50 * 12$ \\
\hline & 29 to 35 & 2.01 & 1.99 & 2.19 & 2.01 & 2.02 & 7.62 & $1.38 \mathrm{~ns}$ \\
\hline & 36 to 42 & 2.15 & 2.21 & 2.18 & 2.31 & 2.28 & 7.44 & $0.86 \mathrm{~ns}$ \\
\hline & 1 to 42 & 1.72 & 1.76 & 1.80 & 1.84 & 1.88 & 2.02 & $68.10 * * 13$ \\
\hline
\end{tabular}

$1 \hat{\mathrm{Y}}=199.17-0.95 \mathrm{TW}\left(\mathrm{R}^{2}=0.49\right) ;{ }^{2} \hat{\mathrm{Y}}=462.85+1.988 \mathrm{TW}-0.1764 \mathrm{RT}^{2}\left(\mathrm{R}^{2}=0.97\right) ;{ }^{3} \hat{\mathrm{Y}}=1.256 .57+6.774 \mathrm{TW}\left(\mathrm{R}^{2}=0.92\right) ; 4 \hat{\mathrm{Y}}=173.31+0.3759 \mathrm{TW}-0.1101 \mathrm{TW}{ }^{2}$ $\left(\mathrm{R}_{\hat{\mathrm{Y}}}^{2}=0.96\right) ;{ }^{5} \hat{\mathrm{Y}}=359.73-2.4439 \mathrm{TW}\left(\mathrm{R}_{\hat{\mathrm{Y}}}^{2}=0.92\right) ;{ }^{6} \hat{\mathrm{Y}}=573.61-3.5262 \mathrm{TW}\left(\mathrm{R}^{2}=0.87\right) ;{ }^{7} \hat{\mathrm{Y}}=608.29-3.3677 \mathrm{TW}\left(\mathrm{R}^{2}=0.81\right) ;{ }^{8} \hat{\mathrm{Y}}=2,878.60-8.26 \mathrm{TW}\left(\mathrm{R}^{2}=0.76\right) ;$ $9 \hat{\mathrm{Y}}=1.10+0.0084 \mathrm{TW}\left(\mathrm{R}^{2}=0.64\right) ; 10 \hat{\mathrm{Y}}=1.30+0.0056 \mathrm{TW}\left(\mathrm{R}^{2}=0.81\right) ; 11 \hat{\mathrm{Y}}=1.41+0.0084 \mathrm{TW}\left(\mathrm{R}^{2}=0.91\right) ;{ }^{12} \hat{\mathrm{Y}}=1.73-0.0036 \mathrm{TW}+0.0008 \mathrm{TW}\left(\mathrm{R}^{2}=0.81\right) ;$ $13 \hat{\mathrm{Y}}=1.72+0.008 \mathrm{TW}\left(\mathrm{R}^{2}=0.97\right)$

$*$ and $* *=$ Significant at 5 and $1 \%$ of probability, respectively; ns $=$ Not-significant at $5 \%$ of probability. 
Table 4 - Means of absolute and relative weight at slaughter of guttered carcass, gutted carcass without feet and head and primal cuts at 42 days old fed ration containing tomato waste

\begin{tabular}{|c|c|c|c|c|c|c|c|}
\hline \multirow[t]{2}{*}{ Item } & \multicolumn{5}{|c|}{ Level of tomato waste (\%) } & \multirow[t]{2}{*}{$\mathrm{CV}$} & \multirow[t]{2}{*}{ F (\%) } \\
\hline & 0 & 5 & 10 & 15 & 20 & & \\
\hline \multicolumn{8}{|c|}{ Absolute weight (g) } \\
\hline Live weight & $2,870.80$ & $2,876.10$ & $2,799.40$ & $2,812.60$ & $2,724.60$ & 4.75 & $1.07 \mathrm{~ns}$ \\
\hline Carcass & $2,578.50$ & $2,539.85$ & $2,501.20$ & $2,462.55$ & $2,423.90$ & 5.01 & $4.76 *(1)$ \\
\hline Carcass without feet and head & $2,402.94$ & $2,365.37$ & $2,327.80$ & $2,290.23$ & $2,252.66$ & 5.20 & $8.83 *(2)$ \\
\hline Breast & 764.60 & 742.20 & 722.60 & 729.00 & 696.20 & 8.17 & $0.89 \mathrm{~ns}$ \\
\hline Drumstick & 301.12 & 296.60 & 292.08 & 287.56 & 283.04 & 5.20 & $4.43 *(3)$ \\
\hline Thigh & 371.12 & 360.06 & 349.00 & 337.94 & 326.88 & 6.85 & $10.69 * *(4)$ \\
\hline \multicolumn{8}{|c|}{ Relative weight (\%) } \\
\hline Carcass & 89.44 & 89.10 & 88.76 & 87.89 & 88.76 & 1.23 & $1.40 \mathrm{~ns}$ \\
\hline Carcass without feet and head & 83.42 & 82.95 & 82.46 & 81.79 & 82.52 & 1.37 & $1.44 \mathrm{~ns}$ \\
\hline Breast & 29.70 & 28.94 & 29.31 & 29.42 & 28.74 & 4.54 & $0.42 \mathrm{~ns}$ \\
\hline Drumstick & 11.39 & 12.00 & 11.77 & 11.67 & 11.55 & 4.03 & $1.20 \mathrm{~ns}$ \\
\hline Thigh & 14.84 & 13.65 & 13.37 & 14.38 & 13.45 & 7.62 & $1.82 \mathrm{~ns}$ \\
\hline
\end{tabular}

${ }_{1} \hat{Y}=2,578.50-7.73 T W\left(R^{2}=0.93 \%\right) ;{ }^{2} \hat{Y}=2,402.94-7,514 T W\left(R^{2}=0.93 \%\right) ;{ }^{3} \hat{Y}=301.12-0.904 T W\left(R^{2}=0.49 \%\right) ;{ }^{4} \hat{Y}=371.12-2.21244 T W\left(R^{2}=0.59 \%\right)$.

$*$ and $* *=$ Significant at 5 and $1 \%$ of probability, respectively; ns $=$ Not significant at $5 \%$ of probability.

carcass weight, carcass without feet and head, drumstick and thigh, there was a linear effect, because, for each $1 \%$ of tomato waste inclusion, there were decreases of $7.73 ; 7.51$; 0.90 and $2.21 \mathrm{~g}$, respectively (Table 4). Loureiro et. al. (2007) also observed negative linear effect for mass of eggs and weight of yolk in the total period from 30 to 39 weeks when using the same levels of tomato waste in ration of commercial laying hens.

There was no difference between diets of tomato waste for absolute weight and wing yield, back and abdominal fat (Table 5), whose observed means for absolute weight were of 220.36; 387.40 and of $64.43 \mathrm{~g}$, respectively, and, for relative weight, of $8.81 ; 15.49$ and $2.57 \%$, respectively.

Loureiro et. al. (2007) also obtained results similar to the ones related in this research and did not observe any significant difference in the percentage of yolk in the period from 36 to 39 weeks neither in the percentage of albumen in the period from 33 to 36 weeks, as well as Cavalcante et al. (2007) observed no difference between diets with $17.5 \%$ of coconut meal regarding wing yield, back and belly fat of broiler chickens.

There was no difference between regime with different levels of tomato waste for absolute weight of heart, liver and gizzard neither for yield of gizzard (Table 6), with means of $13.35 \mathrm{~g} ; 41.83 \mathrm{~g} ; 34.87 \mathrm{~g}$ and $1.94 \%$, respectively. However, for yield of heart and liver, there was linear effect, because for each $1 \%$ of tomato waste inclusion, there was an increase of 0.0036 and $0.0133 \%$, respectively.

Differences regarding to the weight of carcass and parts are accounted for the use of tomato waste in early phases of breeding, that is, weight gain was significantly affected up to 29 days of age, but after this age it was verified that use of tomato waste up to the level of $20 \%$ did no affect significantly weight gain and food conversion for broiler chickens. On the other hand, during the period from 29 to 42 days of age, birds consuming ration containing waste did not recover body weight. Therefore, according to

Table 5 - Means of absolute and relative weights of non primal cuts and belly fat of broiler chicken at 42 days old fed rations containing tomato waste

\begin{tabular}{|c|c|c|c|c|c|c|c|}
\hline \multirow[t]{2}{*}{ Item } & \multicolumn{5}{|c|}{ Level of tomato waste (\%) } & \multirow[t]{2}{*}{ CV (\%) } & \multirow[t]{2}{*}{$\mathrm{F}$} \\
\hline & 0 & 5 & 10 & 15 & 20 & & \\
\hline \multicolumn{8}{|c|}{ Absolute weight (g) } \\
\hline Wings & 224.80 & 218.80 & 222.00 & 221.60 & 214.6 & 06.65 & $0.35 n s$ \\
\hline Back & 375.60 & 395.80 & 396.80 & 379.60 & 389.20 & 9.12 & $0.36 \mathrm{~ns}$ \\
\hline Abdominal fat & 68.43 & 68.43 & 64.19 & 60.19 & 60.92 & 21.38 & $0.41 \mathrm{~ns}$ \\
\hline \multicolumn{8}{|c|}{ Relative weight (\%) } \\
\hline Wings & 8.74 & 8.56 & 8.94 & 8.96 & 8.87 & 5.43 & $0.60 \mathrm{~ns}$ \\
\hline Back & 14.60 & 15.42 & 15.95 & 15.38 & 16.09 & 7.24 & $1.37 \mathrm{~ns}$ \\
\hline Abdominal fat & 2.65 & 2.69 & 2.58 & 2.43 & 2.53 & 20.78 & $0.18 \mathrm{~ns}$ \\
\hline
\end{tabular}


Table 6 - Means of absolute and relative weight of edible guts from cuts of 42 days old fed ration containing tomato waste

\begin{tabular}{|c|c|c|c|c|c|c|c|}
\hline \multirow[t]{2}{*}{ Item } & \multicolumn{5}{|c|}{ Tomato waste (\%) } & \multirow[t]{2}{*}{ CV (\%) } & \multirow[t]{2}{*}{$\mathrm{F}$} \\
\hline & 0 & 5 & 10 & 15 & 20 & & \\
\hline \multicolumn{8}{|c|}{ Absolute weight (g) } \\
\hline Heart & 12.93 & 12.99 & 13.38 & 13.78 & 13.65 & 12.15 & $0.27 \mathrm{~ns}$ \\
\hline Liver & 39.93 & 39.66 & 43.31 & 43.10 & 43.14 & 9.04 & $1.21 \mathrm{~ns}$ \\
\hline Gizzard & 32.62 & 36.56 & 35.29 & 34.92 & 34.98 & 5.83 & $2.45 \mathrm{~ns}$ \\
\hline \multicolumn{8}{|c|}{ Relative weight (\%) } \\
\hline Heart & 0.50 & 0.52 & 0.53 & 0.55 & 0.57 & 11.26 & $4.40 *(1)$ \\
\hline Liver & 1.54 & 1.61 & 1.68 & 1.74 & 1.81 & 9.59 & $8.53 * *(2)$ \\
\hline Gizzard & 1.81 & 1.99 & 1.76 & 2.10 & 2.03 & 11.15 & $2.27 \mathrm{~ns}$ \\
\hline
\end{tabular}

(1) $\hat{\mathrm{Y}}=0.4976+0.0036 \mathrm{TW}\left(\mathrm{R}^{2}=0.93 \%\right) ;(2) \hat{\mathrm{Y}}=1.5432+0.0133 \mathrm{TW}\left(\mathrm{R}^{2}=0.82 \%\right)$.

this study, it is recommended to use tomato waste starting from 29 days of age to avoid lower weight, mainly for the noble parts of carcass.

\section{Conclusions}

The use of waste in broiler chicken rations during the period from 1 to 28 days may decrease weight gain and worsen feed conversion.

Tomato waste may be used as ingredient in broiler chickens ration from 29 to 42 days of age up to level of $20 \%$ without harming weight gain and feed conversion of birds.

\section{Acknowledgments}

The authors thank the Fundação de Amparo à Pesquisa do Estado de Pernambuco (FACEPE) for financing part of the research and the Centro de Ciências Agrárias da Universidade Federal de Alagoas (CECA/UFAL) for the supporting; the TAMBAÚ Company for donating the guava waste; the Pró-reitoria de Pesquisa e Pós-graduação da Universidade Federal Rural de Pernambuco for supporting the publishing of this article.

\section{References}

ABREU, P.G.; ABREU, V.M.N. Ventilação na avicultura de corte. Concórdia: Embrapa Suínos e Aves, 2000. 50p. (Documentos, 63).

AL-BETAWI, N.A. Preliminary study on tomato pomace as unusual feedstuff in broiler diets. Pack Journal of Nutrition, v.4, p.57-63, 2005.

BUFFINGTON, D.E.; COLAZZO-AROCHO, A.; CANTON, G.H. Black globe-humidity index (BGHI) as comfort equation for dairy cows. Transaction of the ASAE, v.24, p.711-714, 1981.

CAVALCANTE, S.B.; FUENTES, M.F.F.; FREITAS, E.R. et al. Efeito da inclusão de farelo de coco em rações para frangos de corte. Revista Ciência Agronômica, v.38, n.3, p.297-303, 2007.

COUSINS, B. Enzimas na nutrição de aves. In: SIMPÓSIO INTERNACIONAL ACAV - EMBRAPA SOBRE NUTRIÇÃO
DE AVES, 1., 1999, Concórdia. Anais... Concórdia: Embrapa Aves e Suínos, 1999. p.118-132.

EZEQUIEL, J.M.B.; SILVA, O.G.C.E.; GALATI, R.L. et al. Desempenho de novilhos nelore alimentados com casca de soja ou farelo de gérmen de milho em substituição parcial ao milho moído. Revista Brasileira de Zootecnia, v.35, n.2, p.569-575, 2006.

FERREIRA, D.F. Programa SISVAR - Sistema de Análise de Variância. Versão 4,6 (Build 6,0). Lavras: DEX/UFLA, 2003. INSTITUO BRASILEIRO DE GEOGRAFIA E ESTATÍSTICAS IBGE. [2005]. LPSA - Levantamento sistemático da produção agrícola em fevereiro de 2005. Disponível em: <www.sidra.ibge.gov.br/bda/tabela>. Acesso em: 15/4/2006.

JAFARI, M.; PIRMOHAMMADI, R.; BAMPIDIS, V. The use of dried tomato pulp in diets of laying hens. International Journal of Poultry Science, v.5, n.7, p.618-622, 2006.

KRONKA, R.N.; SPERS, A.; SILVEIRA, J.J.N. et al. Subproduto da industrialização do tomate em rações de suínos em crescimentos e acabamento. Boletim Indústria Animal, v.27/28, n. único, p.101-107, 1971 .

LIRA, R.C. Valor nutricional e utilização do resíduo da goiaba (Psidium guajava l.) e do tomate (Lycopersicum esculentum mill.) na alimentação de frangos de corte. 2008. 105f. Tese (Doutorado em Zootecnia) - Universidade Federal Rural de Pernambuco, Recife.

LOUREIRO, R.R.S. Farelo de tomate (Lycopersicum esculentum Mill.) na alimentação de poedeiras comerciais. Acta Scientiarum. Animal Science, v.29, n.4, p.387-394, 2007.

PARSONS, C.M.A.; POTTER, L.M.; BLISS, B.A. True metabolizable energy corrected to nitrogen equilibrium. Poultry Science, v.61, n.11, p.2241-2246, 1985

PERSIA, M.E.; PARSONS, C.M.; SCHANG, M. et al. Nutritional evaluation of dried tomato seeds. Poultry Science, v.82, n.1, p.141-146, 2003.

PHILIP, J.S.; GILBERT, H.J.; SWITHARD, R.R. Growth, viscosity and beta-glucanase activity of intestinal fluid in broiler chickens feed on barley-based diets with or without exogenous beta glucanase. British Poultry Science, v.36, p.599-605, 1995.

POTTER. B.A.; FRIESEN, O.D.; GUENTER, W. et al. Influence of enzyme suplementation on the bioavailable energy of barley. Poultry Science, v.69, p.1174-1181, 1990.

RIBEIRO, A.C.; RIBEIRO, S.D.A.; ANTÔNIO, M.S. et al. Composição química de diferentes resíduos da agroindústria do tomate destinado à alimentação animal. In: REUNIÃO ANUAL DA SOCIEDADE BRASILEIRA DE ZOOTECNIA, 41., 2004, Campo Grande. Anais... Campo Grande: SBZ, 2004. (CD-ROM).

RODRIGUES, P.B.; DUTRA JR., W.M.; ROSTAGNO, H.S. et al. Valores energéticos e aminoácidos digestíveis do capim arroz para aves. Revista Brasileira de Zootecnia, v.33, n.5, p.1192-1196, 2004. ROSTAGnO, H.S.; ALBINO, L.T.; DONZELE, J.L et al. Tabelas brasileiras para aves e suínos. Composição de alimentos e exigências nutricionais. 2.ed. Viçosa, MG: UFV, 2005. 186p. 
SILVA, E.P.; SILVA, D.A.T.; RABELLO, C.B.V. et al. Composição físico-química e valores energéticos dos resíduos de goiaba e tomate para frangos de corte de crescimento lento. Revista Brasileira de Zootecnia, v.38, n.6, p.1051-1058, 2009.

SOARES, M.B.P.; FUENTES, M.F.F.; FREITAS, E.R. et al. Farelo de amêndoa da castanha de caju na alimentação de codornas japonesas na fase de postura. Revista Brasileira de Zootecnia, v.36, n.4, p.1076-1082, 2007 (supl.).

TEIXEIRA, V.H. Estudo dos índices de conforto em duas instalações de frango de corte para as regiões de Viçosa e Visconde do Rio Branco. 1983. 59f. Dissertação (Mestrado em Zootecnia) - Universidade Federal de Viçosa, Viçosa, MG.

TORRES, D.M. Valor nutricional de farelos de arroz suplementados com fitase, determinado por diferentes metodologias com aves. Lavras, 2003. 172p. Tese (Doutorado em Zootecnia) - Universidade Federal de Lavras, Lavras.

YANNAKOPOULOS, A.L.; TSERVENI-GOUSI, A.S.; CHRISTAKI, E.V. Effects of locally produced tomato meal on the performance and egg quality of laying hens. Annual Feed Science Technology, v.36, n.1, p.53-57, 1971. 